\title{
Article
}

\section{Not all that Glitters is Gold: ICT and Inclusive Human Development in Sub- Saharan Africa}

\author{
Asongu, Simplice and Nwachukwu, Jacinta Chikaodi \\ Available at http://clok.uclan.ac.uk/25157/ \\ Asongu, Simplice and Nwachukwu, Jacinta Chikaodi ORCID: 0000-0003-2987- \\ 9242 (2017) Not all that Glitters is Gold: ICT and Inclusive Human \\ Development in Sub-Saharan Africa. International Journal of Happiness and \\ Development, 3 (4). pp. 303-322. ISSN 2049-2790
}

It is advisable to refer to the publisher's version if you intend to cite from the work.

http://dx.doi.org/10.1504/JHD.2017.087932

For more information about UCLan's research in this area go to http://www.uclan.ac.uk/researchgroups/ and search for < name of research Group>.

For information about Research generally at UCLan please go to http://www.uclan.ac.uk/research/

All outputs in CLoK are protected by Intellectual Property Rights law, including Copyright law. Copyright, IPR and Moral Rights for the works on this site are retained by the individual authors and/or other copyright owners. Terms and conditions for use of this material are defined in the policies page.

\section{CLoK}

Central Lancashire online Knowledge www.clok.uclan.ac.uk

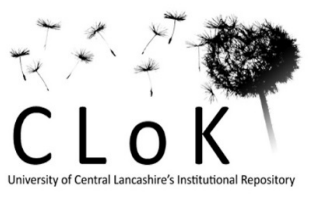





\title{
Not all that Glitters is Gold: ICT and Inclusive Human Development in Sub-Saharan Africa
}

Forthcoming: International Journal of Happiness and Development

\author{
Simplice A. Asongu \\ African Governance and Development Institute, \\ P.O. Box 8413, Yaoundé, Cameroon. \\ E-mail: asongusimplice@yahoo.com \\ Jacinta C. Nwachukwu \\ School of Economics, Finance and Accounting, \\ Faculty of Business and Law, \\ Coventry University Priory Street, Coventry, CV1 5FB, UK \\ Email: jacinta.nwachukwu@ coventry.ac.uk
}




\title{
Not all that Glitters is Gold: ICT and Inclusive Human Development in Sub-Saharan Africa
}

\begin{abstract}
This paper examines the short and long term effects of information and communication technology (ICT) on inclusive human development in a panel of 49 Sub-Saharan African countries for the period 2000-2012. ICT is measured in terms of mobile phone penetration, internet penetration and telephone penetration rates. While mobile phone penetration has positive short run and long term effects on inclusive human development, the effects of internet and telephone penetrations are insignificant. Moreover, the long term inclusive human development benefits of the mobile phone are higher than the corresponding short term rewards. Policy implications are discussed.
\end{abstract}

JEL Classification: G20; I10; I32; O40; O55

Keywords: ICT; inclusive human development; Africa 


\section{Introduction}

Investigating the relevance of ICT in inclusive development in Sub-Saharan Africa (SSA) fundamentally builds on four principal factors. They include the fact that the region is characterised by, inter alia: (i) a lagging status in knowledge-based economies; (ii) growing poverty levels; (iii) greater opportunities for ICT penetration and (iv) a stream of recent literature on the benefits of ICT for inclusive human development.

First, it is now clear that globalisation is an indispensable phenomenon which can only be neglected by nation states at the price of jeopardising their prosperity as well as those of their citizens. Accordingly, it is a hard fact that for countries to be competitive in the global arena, they have to play by the rules imposed by the competitive process of globalisation. In the $21^{\text {st }}$ century, such competition is fundamentally centred on knowledge-based economies (see Asongu, 2015a; Tchamyou, 2016; Oluwatobi et al., 2015). Generally speaking, these authors emphasised the following three key outcomes: (i) the mechanics of knowledge economy have been mastered by European and North American countries. These states are steering the speed and nature of economic development in the international arena (ii) the historic road map formulated by Japan has set the pace for Malaysia, China and the Newly Industrialised countries in Asia (Taiwan, South Korea, Hong Kong and Singapore) (iii) economies of Latin America are responding in considered steps that underscore the relevance of knowledge in the pursuit of national and regional goals. Unfortunately, whereas the knowledge economy trend is encouraging for other regions of the world, the overall index in Africa has been decreasing since the year 2000 (see Anyanwu, 2012; Asongu, 2015b).

Second, with regard to increasing poverty levels in Africa, a report in 2015 by the World Bank on the achievement of Millennium Development Goals (MDGs) has revealed that extreme poverty has been decreasing in all regions of the world with the exception of Africa where close to half of the countries in sub-region were substantially off-track from attaining the MDG extreme poverty target (World Bank, 2015). It is interesting to note that this puzzling statistic is discouraging because the sub-region has been enjoying more than two decades of resurgence in growth that began in the mid-1990s (see Fosu, 2015a, p. 44). The troubling extreme poverty trends in Africa have motivated a growing stream of literature that is focused on elucidating the continent's human welfare tragedy. For instance, Kuada (2015) has proposed a paradigm shift to soft economics or human development as a means to understanding the poverty trends in the continent. Fosu (2015bc) has edited a plethora of studies dedicated to investigating if the growth resurgence in the continent is a myth or reality. There are also branches of the literature that have focused on, inter alia: (i) correlates 
of poverty (Anyanwu, 2013a, 2014a); (ii) gender equality (Elu \& Loubert, 2013; Anyanwu, 2013b, 2014b; Baliamoune-Lutz, 2007 \& McGillivray, 2009; Baliamoune-Lutz, 2007) and (iii) reinventing foreign aid for employment with inclusive and sustainable development (see Jones \& Tarp, 2015; Simpasa et al., 2015; Jones et al., 2015) ${ }^{1}$.

Third, compared with other regions of the world, the potential for ICT penetration in Africa is greatest. Penard et al. (2012) and Asongu (2015c) have recently shown that the possibilities for internet and mobile phone penetrations are substantially higher in Africa. The implication is that ICT has the potential to generate a number of inclusive development externalities. By contrast, ICT penetration rate in high-end markets in North America and Europe are reaching saturation points.

Fourth, an interesting body of literature has documented a multitude of rewards from ICT in less developed countries. Such benefits have included: (i) greater opportunities for entrepreneurial activities (Ondiege, 2010, p. 11); (ii) more efficiency in household management (Asongu, 2014a; Al Surikhi, 2012); (iii) purging of agricultural wastes through reductions in supply-demand mismatches as well as constraints from the demand and supply sides (see Muto \& Yamano, 2009; Aker \& Fafchamps, 2010); (iv) enhancement of inclusive finance (see Kirui et al. 2013, p. 141; Singh, 2012, p. 466); (v) narrowing of gaps between urban and rural development (see Chan \& Jia, 2011, pp. 3-5; Qiang et al., 2011, pp. 14-26); (vi) empowerment of women from an economic standpoint (Ojo et al., 2012; Maurer, 2008); (vii) mitigation of income inequality (Asongu, 2015d) and (viii) promotion of informal finance at the expense of formal financial development (Asongu, 2013a).

In the light of the above motivations, this study contributes to the extant literature by investigating the effect of ICT on inclusive human development in Sub-Saharan Africa. The study in the literature that is closest to this inquiry is Asongu (2015d) which employs exclusively mobile penetration as the ICT indicator. Moreover, the study is based on crosssectional data (of the year 2009), such that the findings can only be interpreted as correlations, not causality. Such leaves very little room for sound policy implications. Hence, the present study is novel by using a panel sample for the period 2000-2012 to assess both long and short term effects of ICT on inclusive human development. The estimation technique is also designed to address concerns of simultaneity and the unobserved heterogeneity which are possible causes of endogeneity in Asongu (2015d). In essence, whereas the fourth motivation

\footnotetext{
${ }^{1}$ There is also an interesting body of literature on the relationship between aid, happiness and well-being (see Arvin \& Lew, 2010ab, 2011, 2012ab).
} 
is substantiated in Section 2 in order to clearly show how the present inquiry contributes to the extant literature, the cotemporary policy relevance of the inquiry has been articulated in the first-three motivations. Regardless of the incentives for the study, scholars are increasingly cautioning ICT not to be considered as a silver bullet for economic development (Mpogole et al., 2008, p. 71; Asongu \& Nwachukwu 2016a).

The rest of the inquiry is organized in the following manner. The theoretical underpinnings and related literature on the nexus between ICT and development outcomes are presented in Section 2. Section 3 discusses the data and methodology while Section 4 reports the empirical results. Section 5 concludes with implications and future research directions.

\section{Related literature and theoretical underpinnings}

\subsection{ICT and inclusive development}

There are a multitude of inclusive development rewards from ICT penetration in developing countries. As recently documented by Asongu and Nwachukwu (2016b), the benefits of ICT are apparent in almost every fabric of African society. The authors have maintained that such positive rewards include: (i) better mechanisms of health care monitoring, (ii) improvement of household-to-household, business-to-business and household-to-business networks; (iii) consolidation of payment facilities in small and medium corporations and (iv) the bridging of development gaps between rural and urban areas. These salient advantages are summarized in the subsequent paragraphs in three main categories, namely in terms of: (i) reducing the gender gap; (ii) enhancing health services and (iii) mitigating the rural-urban development gap.

In the first category, a substantial part of the literature has been documented on the relevance of ICT in non-exclusive development, notably in terms of how women are empowered via mechanisms of financial inclusion. Some of the documented mechanisms have comprised better management of small and medium sized corporations by female entrepreneurs and enhanced coordination in the management of households (Asongu, 2014a). Other recognized benefits are, among others: education, cost-effectiveness, multi-tasking and better gender equality policies from governments (see Jonathan \& Camilo, 2008; Maurer, 2008; Ojo et al (2012); Ondiege, 2010, 2013; Al Surikhi, 2012; Asongu, 2015d)².

In the second classification, benefits are apparent in a growing stream of literature on the importance of ICT in improving the delivery of health services. Accordingly, ICT enables

\footnotetext{
${ }^{2}$ We invite the interested reader to consult Bisht (2013, p. 505) and Ondiege (2010, p.11) for country-specific approaches, strategies and coordination in ICT policy for the livelihood of females.
} 
facilities that render medical services more affordable (see West, 2013). Hence, income and geography barriers which traditionally limit access to health care are increasingly being lifted with the help of ICT. Some of the documented mechanisms through which such positive externalities can be achieved are: efficiency in laboratory tests, examination of medical records and access to referenced medical material. Such medical services have been adapted with ICT to: (i) enhance patient feedback as well as boost self-monitoring (Bauer et al., 2010); (ii) consolidate treatment and observation of sick people with tuberculosis (Hoffman et al., 2010) and (iii) provide more effective organization and management of appointments in clinics and hospitals (De Costa et al., 2010). The population that is benefiting most from this improvement in health services is in rural areas with geographical and income barriers (see Kliner et al., 2013). The stance of Kliner et al. (2013) on the substantial weight that ICT exerts in reducing poverty in rural communities has been confirmed by Kirui et al. (2013): 'We conclude that mobile phone-based money transfer services in rural areas help to resolve a market failure that farmers face; access to financial services' (p. 141).

In the third aspect on how ICT reduces the rural-urban gap, the relevant literature can be discussed in three main strands, notably, in terms of: (i) tackling unemployment issues on the one hand and on the other, addressing concerns in the production and distribution of food; (ii) supporting start-ups like small and medium corporations and cooperatives and (iii) reducing supply-side and demand-side obstacles to productivity in the agricultural sector.

In the first strand, obstacles to employment on the one hand and on the other, the production and distribution of agricultural products in rural communities are increasingly being limited with the employment of ICT applications. (1) As a case in point, E-agriculture (2012, p. 6-9) has shown that traders have the possibility of increasing their incomes by as much as 10 percent with the help of ICT applications on market data. (2) ICT improves the livelihood of the population in rural areas by breaking barriers to production in agriculture and reducing demand/supply related limitations (see Muto \& Yamano, 2009; Aker \& Fafchamps, 2010). Moreover, the income of farmers can be increased if agricultural constrictions are restricted through networking mechanisms and 'matching practices' (Asongu\& Nwachukwu, 2016b). (3) In rural communities, ICT-related services (e.g. mobile banking) are boosting agricultural finance by consolidating small corporations and cooperatives. For example, in Costa Rica the Community Credit Enterprises (CCE) are enabling the: (i) development of business models that are sustainable and (ii) support of financially viable groups (Perez et al., 2011, p. 316). 
The above narratives in the third category are broadly in line with the World Bank on the importance of ICT in agricultural and rural developments (see Qiang et al., 2011, pp. 1426). The view is shared by Chan and Jia (2011) on the benefits of ICT in financial access 'mobile banking is an ideal choice for meeting the rural financial needs' (p. 3), partially due to the growing 'rates for bank transfers through mobile cell phones at commercial banks' ( $\mathrm{p}$. 5). As shown by Warren (2007), the positive rewards from ICT are noticeable in rural areas. This is partly traceable to the fact that by acting as an information sharing mechanism, ICT mitigates information asymmetry by breaking barriers to the purchase of commodities and acquisition of information. As a case in point, ICT is increasing inclusive finance in Indian rural communities (see Singh, 2012, p. 466), partly because in the country, 'Telecommunication infrastructure growth especially mobile phone penetration has created an opportunity for providing financial inclusion' (Mishra \& Bisht, 2013, p. 503).

\subsection{Intuition and theoretical underpinnings}

The theoretical foundations of the inquiry are broadly in accordance with income convergence literature that has been substantially documented within the context of neoclassical growth frameworks (Barro, 1991; Baumol, 1986; Mankiw et al., 1992; Barro \& Sala-i-Martin, 1992, 1995) and recently extended to other fields of economic development, notably, in: financial markets (see Narayan et al., 2012; Bruno et al., 2012); negative economic and institutional signals (Asongu \& Nwachukwu, 2016cd) and inclusive human development (Asongu, 2014b). The two views accord with the hypothesis that reducing cross-country variations in underlying factors is the foundation of common policies.

In the post-Keynesian epoch, growth theories that became popular with the reemergence of the classical revolution have eased cross-country reduction in differences in per capita income. Under this canopy, the relevance of economic growth theories based on catchup was provided by an extension of market equilibrium concepts. Within this framework, declining cross-country differences in per capita income level is the outcome of policies that are in accordance with 'free-market competition' (Mayer-Foulkes, 2010).

The engaged theoretical framework aligns with the present inquiry in that we are employing an estimation technique that models catch-up in inclusive human development. Moreover, variables in the conditional information set used to assess the presence of such catch-up include ICT. In other words, there is an underlying hypothesis that when ICT is combined with other macroeconomic factors in the conditioning information set, some form of catch-up in inclusive human development is facilitated among countries in SSA. 


\section{Data and methodology}

\subsection{Data}

The study assesses a panel of forty-nine countries in Sub-Saharan Africa with data from the United Nations Development Programme (UNDP) and the African Development Indicators of the World Bank for the period 2000-2012. Borrowing from recent literature on inclusive development in Africa (Asongu et al., 2015), the dependent variable is proxied with the inequality adjusted human development index (IHDI). The human development index (HDI) can be defined as the mean of achievements in the following three principal categories: (i) decent living standards; (ii) knowledge and (iii) long life and health. Further to taking the underlying achievements into consideration, the IHDI also controls for how such achievements are distributed within the population by factoring the mean value of each dimension with the corresponding level of inequality. The proxy is better for inclusive development because it integrates both the 'absolute pro-poor' and 'relative pro-poor' concepts of inclusive development since it accounts for poverty and inequality in that order. Whereas poverty is considered because it is closely related to the aforementioned components of human development, inequality is also integrated because the underlying three components are adjusted for disparity in living standards. It is important to note that both the relative propoor growth (Dollar \& Kraay, 2002) and absolute pro-poor growth (Ravallion \& Chen, 2003) concepts are adopted by the study. Such mitigates the implications of the criticisms by Lopez \& Serven, (2004) and Klasen (2005) on studies in which the measurement of inclusive development is entirely limited to monetary aspects. In summary, our choice of inclusive development indicator include: (i) pro-poor ameliorations in social opportunities and (ii) equal access to economic opportunities. Besides, the concept, definition and measurement of our indicator of IHDI are consistent with at least six of the seventeen SDGs ${ }^{3}$.

Consistent with the recent African knowledge economy literature (Penard et al., 2012; Tchamyou, 2016; Asongu, 2015c), three ICT variables are employed, namely: mobile phone penetration, internet penetration and telephone penetration.

\footnotetext{
${ }^{3}$ Consistent with Michel (2016), the six sustainable development goals (SDGs) include: Goal 1('end poverty in all its forms everywhere'), Goal 2 ('end hunger, achieve food security and improved nutrition and promote sustainable agriculture'); Goal 3 ('ensure healthy lives and promote well-being for all ages'); Goal 4 ('ensure inclusive and equitable quality education and promote lifelong learning opportunities for all'); Goal 8 ('promote sustained, inclusive and sustainable economic growth, full and productive employment and decent work for all' ) and Goal 10 (reduce inequality within and among countries).
} 
This study includes five main additional variables in order to control for omitted variable bias: They are: (i) the lag of the dependent variable, (ii) overseas development assistance, (iii) private domestic credit, (iv) remittances and (v) foreign direct investment. First, the impact of foreign aid on inclusive human development in Africa is still subject to debate. From recent literature, whereas Asongu (2014e) has concluded that foreign aid is perilous to inclusive human development in the continent, Asongu and Nwachukwu (2016e) have clarified Asongu (2014e) by suggesting that the effect may either be positive or negative depending on the estimation techniques, periodicity of study and whether the unobserved heterogeneity is sufficiently accounted for. Second, private domestic credit is expected to positively affect inclusive human development because it is a means of ensuring social mobility and reducing unemployment. Third, remittances should positively influence the outcome variable because they are used for consumption purposes, for the most part (see Ssozi \& Asongu, 2016). Fourth, the effect of foreign direct investment (FDI) is inconclusive and could be either positive or negative. The intuition for the expected signs on the control variables is derived from a broad stream of literature on the quality of growth (Mishra et al., 2011; Anand et al., 2012; Seneviratne \& Sun, 2013; Mlachila et al., 2014; Asongu \& Nwachukwu, 2016b).

The definitions of variables (with corresponding sources) are disclosed in Appendix 1 while Appendix 2 provides a summary of statistics for the selected indicators. From these statistics two facts are obvious. On the one hand, the mean values are comparable. On the other, from corresponding standard deviations we can be confident that reasonable estimated linkages will emerge. The correlation matrix is provided in Appendix 3. It enables the study to avoid concerns of multicollinearity that are apparent in the ICT variables.

\subsection{Methodology}

\subsubsection{Specification}

The Generalised Method of Moments (GMM) with forward orthogonal deviations is adopted as our empirical strategy. There are five main factors underlying the choice of this estimation approach. The first and second are fundamental requirements for the employment of the GMM method, whereas the last-three are corresponding advantages. First, the number of cross sections $(\mathrm{N})$ is higher than the number of time series in each cross section $(\mathrm{T})$. This is essentially because we have 49 countries in total and 13 years in each country. Second, the condition for persistence in the outcome variable is fulfilled because the correlation between the inclusive development variable and its first lag is 0.984 , which is above the 0.800 
threshold used to ascertain persistence in an outcome variable. Therefore the lagged dependent variable is included in the model specification. Third, cross-sectional variations are included in the estimation technique. Fourth, the GMM approach also controls for potential endogeneity in all regressosrs by using (i) explanatory variables that are instrumented to control for simultaneity and (ii) time-invariant fixed effect variables to control for the omitted factors and heterogeneity that is unobserved. Fifth, biases of small sample nature in the difference estimator are reduced with the system estimator. It is principally for this last reason that a strong consensus has been established in the literature (see see Bond et al., 2001) on the advantage that the system estimator (Arellano \&Bover, 1995; Blundell \& Bond, 2001) has over the difference estimator (Arellano \& Bond, 1991).

Within the specific context of this inquiry, an extension of Arellano and Bover (1995) by Roodman (2009a, 2009b) is adopted because the estimation approach has been recognised to limit instrument proliferation that could potentially bias estimation output (see Baltagiet al., 2008; Love \& Zicchino, 2006; Asongu \& Nwachukwu, 2016b). In the specification, a twostep procedure is preferred to the one-step because it accounts for heteroscedasticity. It is important to note that the one-step procedure is consistent with homocedasticity.

The following equations in levels (1) and first difference (2) summarize the standard system GMM estimation procedure.

$$
\begin{aligned}
I H D_{i, t}=\sigma_{0}+\sigma_{1} I H D_{i, t-\tau}+\sigma_{2} I C T_{i, t}+\sum_{h=1}^{4} \delta_{h} W_{h, i, t-\tau}+\eta_{i}+\xi_{t}+\varepsilon_{i, t} \\
I H D_{i, t}-I H D_{i, t-\tau}=\sigma_{0}+\sigma_{1}\left(I H D_{i, t-\tau}-I H D_{i, t-2 \tau}\right)+\sigma_{2}\left(I C T_{i, t}-I C T_{i, t-\tau}\right) \\
+\sum_{h=1}^{4} \delta_{h}\left(W_{h, i, t-\tau}-W_{h, i, t-2 \tau}\right)+\left(\xi_{t}-\xi_{t-\tau}\right)+\varepsilon_{i, t-\tau}
\end{aligned}
$$

Where: $I H D_{i, t}$ is inclusive human development for country $i$ at period $t ; \partial$ is a constant; $I C T$, is information and communication technology (mobile phone penetration, internet penetration and telephone penetration); $W$ is the vector of control variables (Foreign aid, Private domestic credit, Remittances and Foreign direct investment); $\tau$ represents the coefficient of serial correlation, $\xi_{t}$ is the time-specific constant, $\eta_{i}$ is the country-specific effect and $\varepsilon_{i, t}$ the error term.

\subsubsection{Identification, simultaneity and exclusion restrictions}

Borrowing from recent literature (see Dewan \& Ramaprasad, 2014; Asongu \& De Moor, 2016), all independent indicators are considered as predetermined or suspected endogenous variables. Time-invariant omitted indicators are treated exclusively as strictly exogenous 
while the procedure for treating the corresponding ivstyle(years) is 'iv(years, eq(diff))'. This is essentially because it is not very likely for years to become endogenous after firstdifference (see Roodman, 2009b).

The issue of simultaneity is tackled with lagged regressors that are employed as instruments for indicators that are forward-differenced. Accordingly, the fixed effects that could eventually affect the investigated linkages are purged using Helmet transformation on the regressors (see Arellano \& Bover, 1995; Love \& Zicchino, 2006). The conversions entail forward average-differencing of the variables: the average of all future observations is deducted from the indicators, as opposed to deducting past observations from the present ones. Such transformation permits orthogonal or parallel conditions between lagged values and forward-differenced variables. Regardless of lag number, in order to keep data loss at minimum, the suggested transformations are made for all observations, with the exception of the last observation for each cross section. Moreover "because lagged observations do not enter the formula, they are valid as instruments" (see Roodman, 2009b, p. 104; Asongu \& De Moor, 2016).

As concerns exclusion restrictions, time-invariant omitted variables that are considered as a strictly exogenous influence of the outcome variable exclusively via the suspected endogenous variables. The validity of the exclusion restriction is assessed with the Difference in Hansen Test (DHT) for the exogeneity of instruments. In essence, the null hypothesis for the DHT should not be rejected in order for the outcome variable to be elucidated by the timeinvariant omitted variables exclusively via the suspected endogenous channels. Therefore, the DHT assessment procedure is employed to investigate if time-invariant omitted variables exhibit strict exogeneity by eliciting inclusive human development exclusively via the endogenous explaining mechanisms or variables. Ultimately, in the results that are reported in the following section, the validity of the exclusion restriction is confirmed if the null hypotheses of DHT corresponding to IV (year, eq(diff)) is not rejected.

\section{Empirical results}

Table 1 presents findings on the relationship between ICT and inclusive human development. Four principal information criteria are employed to examine the validity of the GMM model with forward orthogonal deviations ${ }^{4}$. The following findings are established.

\footnotetext{
4 "First, the null hypothesis of the second-order Arellano and Bond autocorrelation test (AR(2)) in difference for the absence of autocorrelation in the residuals should not be rejected. Second the Sargan and Hansen overidentification restrictions (OIR) tests should not be significant because their null hypotheses are the
} 
First, the fact that the estimated coefficients corresponding to the lagged dependent variables are between 0 and 1 implies that some form of catch-up is apparent ${ }^{5}$. In other words, within the sample region of SSA, countries with low levels of inclusive human development are catching-up their counterparts with higher levels of inclusive human development. This evidence of catch-up is consistent with the theoretical underpinnings provided in Section 2. Second, while the mobile phone has positive short run and long term effects on inclusive human development, the effects of internet and telephone penetrations are not significant. Moreover, the long term inclusive benefits of mobile phones are higher than corresponding short term impacts. For example in the second column of Table 1 the short term effect of mobile phone penetration is 0.0002 whereas the corresponding long run impact is 0.0018 (0.0002/ [1-0.889]), where 0.889 corresponds to the estimated lagged value of inclusive human development. Third, most of the significant control variables display expected signs.

\section{Table 1: ICT and Inclusive Human Development (GMM)}

\begin{tabular}{|c|c|c|c|c|c|c|}
\hline \multirow[b]{3}{*}{ Constant } & \multicolumn{6}{|c|}{ Dependent Variable: Inequality Adjusted Human Development } \\
\hline & \multicolumn{2}{|c|}{ Mobile Phone Penetration } & \multicolumn{2}{|c|}{ Internet Penetration } & \multicolumn{2}{|c|}{ Telephone Penetration } \\
\hline & $\begin{array}{l}0.042 * * * \\
(0.000)\end{array}$ & $\begin{array}{l}0.046^{* * * *} \\
(0.000)\end{array}$ & $\begin{array}{l}\mathbf{0 . 0 3 9 * * *} \\
(\mathbf{0 . 0 0 0 )}\end{array}$ & $\begin{array}{l}0.045 * * * \\
(0.000)\end{array}$ & $\begin{array}{l}0.037 * * * \\
(0.000)\end{array}$ & $\begin{array}{l}0.043 * * * * \\
(0.000)\end{array}$ \\
\hline IHDI $(-1)$ & $\begin{array}{l}0.889 * * * \\
(0.000)\end{array}$ & $\begin{array}{l}0.852 * * * * \\
(0.000)\end{array}$ & $\begin{array}{l}0.908 * * * * \\
(0.000)\end{array}$ & $\begin{array}{l}0.909 * * * \\
(0.000)\end{array}$ & $\begin{array}{l}0.922 * * * * \\
(0.000)\end{array}$ & $\begin{array}{l}0.900 * * * * \\
(0.000)\end{array}$ \\
\hline Mobile Phone Penetration & $\begin{array}{l}0.0002 * * \\
(0.019)\end{array}$ & $\begin{array}{l}0.0002 * * \\
(0.010)\end{array}$ & -- & -- & --- & --- \\
\hline Internet Penetration & --- & -- & $\begin{array}{l}0.00007 \\
(0.824)\end{array}$ & $\begin{array}{l}-0.00008 \\
(0.718)\end{array}$ & --- & --- \\
\hline Telephone Penetration & --- & --- & --- & --- & $\begin{array}{l}-0.00003 \\
(0.938)\end{array}$ & $\begin{array}{l}0.0002 \\
(0.429)\end{array}$ \\
\hline Foreign Aid & $\begin{array}{l}-0.0001 * * \\
(0.017)\end{array}$ & $\begin{array}{l}-0.0001 * * \\
(0.011)\end{array}$ & $\begin{array}{l}-0.00007 * * \\
(0.012)\end{array}$ & $\begin{array}{l}-0.00006 * * * \\
(0.002)\end{array}$ & $\begin{array}{l}-0.00005 * * \\
(0.045)\end{array}$ & $\begin{array}{l}-0.0009 * * \\
(0.017)\end{array}$ \\
\hline Private Domestic Credit & $\begin{array}{l}0.0001 \\
(0.538)\end{array}$ & $\begin{array}{l}\text { 0.0004* } \\
(0.059)\end{array}$ & $\begin{array}{l}0.0002 \\
(0.236)\end{array}$ & $\begin{array}{l}\text { 0.0003* } \\
(0.072)\end{array}$ & $\begin{array}{l}0.00001 \\
(0.853)\end{array}$ & $\begin{array}{l}0.0001 * \\
(0.079)\end{array}$ \\
\hline Remittances & $\begin{array}{l}0.00005 \\
(0.784)\end{array}$ & $\begin{array}{l}0.00002 \\
(0.923)\end{array}$ & $\begin{array}{l}0.0001 \\
(0.364)\end{array}$ & $\begin{array}{l}0.0001 \\
(0.667)\end{array}$ & $\begin{array}{l}0.0001 \\
(0.517)\end{array}$ & $\begin{array}{l}0.0002 \\
(0.326)\end{array}$ \\
\hline Foreign Direct Investment & -- & $\begin{array}{l}\mathbf{0 . 0 0 0 2} * * * \\
(\mathbf{0 . 0 0 0 )}\end{array}$ & --- & $\begin{array}{l}0.0002 * * * * \\
(\mathbf{0 . 0 0 0 )}\end{array}$ & --- & $\begin{array}{l}0.0001 * * * * \\
(0.023)\end{array}$ \\
\hline Long Term Effects & 0.0018 & 0.0013 & na & na & na & na \\
\hline $\begin{array}{l}\operatorname{AR}(1) \\
\operatorname{AR}(2) \\
\text { Sargan OIR } \\
\text { Hansen OIR }\end{array}$ & $\begin{array}{l}(0.047) \\
(\mathbf{0 . 2 4 9 )} \\
(0.000) \\
(\mathbf{0 . 5 9 3 )}\end{array}$ & $\begin{array}{l}(\mathbf{0 . 1 8 1}) \\
(\mathbf{0 . 8 5 6 )} \\
(0.000) \\
(\mathbf{0 . 5 7 0})\end{array}$ & $\begin{array}{l}(\mathbf{0 . 1 7 0}) \\
(\mathbf{0 . 3 5 8}) \\
(0.010) \\
(\mathbf{0 . 4 3 9})\end{array}$ & $\begin{array}{l}(\mathbf{0 . 1 0 4 )} \\
(\mathbf{0 . 6 6 3 )} \\
(0.000) \\
(\mathbf{0 . 4 6 5 )}\end{array}$ & $\begin{array}{l}(0.083) \\
(\mathbf{0 . 2 0 6}) \\
(0.014) \\
(\mathbf{0 . 4 1 8})\end{array}$ & $\begin{array}{l}(0.070) \\
(\mathbf{0 . 4 6 0 )} \\
(0.000) \\
(\mathbf{0 . 2 2 1})\end{array}$ \\
\hline DHT for instruments & & & & & & \\
\hline
\end{tabular}

positions that instruments are valid or not correlated with the error terms. In essence, while the Sargan OIR test is not robust but not weakened by instruments, the Hansen OIR is robust but weakened by instruments. In order to restrict identification or limit the proliferation of instruments, we have ensured that instruments are lower than the number of cross-sections in most specifications. Third, the Difference in Hansen Test (DHT) for exogeneity of instruments isalso employed to assess the validity of results from the Hansen OIR test. Fourth, a Fischer test for the joint validity of estimated coefficients is also provided" (Asongu\& De Moor, 2016, p.9)

${ }^{5}$ We invite the interested reader to consult Fung (2009, p. 58), Prochniak and Witkowski (2012a, p. 20), Prochniak and Witkowski (2012b, p. 23) and Asongu (2013b, p. 49) for insights into the criteria for catch-up. 


\begin{tabular}{|c|c|c|c|c|c|c|}
\hline \multirow{2}{*}{\multicolumn{7}{|c|}{ (a)Instruments in levels }} \\
\hline & & & & & & \\
\hline H excluding group & $(0.748)$ & $(0.477)$ & $(\mathbf{0 . 3 3 5})$ & $(0.337)$ & $(0.328)$ & $(0.631)$ \\
\hline Dif(null, $\mathrm{H}=$ exogenous) & $(0.412)$ & $(0.543)$ & $(0.480)$ & (0.519) & (0.459) & (0.123) \\
\hline \multicolumn{7}{|l|}{ (b) IV (years, eq (diff)) } \\
\hline H excluding group & $(0.644)$ & $(0.752)$ & $(0.458)$ & $(0.578)$ & $(0.196)$ & $(0.385)$ \\
\hline Dif(null, $\mathrm{H}=$ exogenous) & $(0.482)$ & $(0.362)$ & (0.397) & $(0.350)$ & $(0.560)$ & (0.191) \\
\hline Fisher & $955.07 * * *$ & $5153.42 * * *$ & $3064.69 * * *$ & $5473.93 * * *$ & $7713.67 * * *$ & $14349.46 * * *$ \\
\hline Instruments & 29 & 33 & 29 & 33 & 29 & 33 \\
\hline Countries & 38 & 38 & 37 & 37 & 36 & 36 \\
\hline Observations & 283 & 283 & 278 & 278 & 278 & 278 \\
\hline
\end{tabular}

***,***: significance levels at 1\%, $5 \%$ and 10\% respectively. DHT: Difference in Hansen Test for Exogeneity of Instruments Subsets. Dif: Difference. OIR: Over-identifying Restrictions Test. The significance of bold values is twofold. 1) The significance of estimated coefficients and the Wald statistics. 2) The failure to reject the null hypotheses of: a) no autocorrelation in the AR(1) \& AR(2) tests and; b) the validity of the instruments in the Sargan OIR test.

\section{Concluding implications and future research directions}

This paper has examined the short and long term effects of information and communication technology (ICT) on inclusive human development in a panel of 49 SubSaharan African countries for the period 2000-2012. ICT is measured in terms of mobile phone penetration, internet penetration and telephone penetration rates. While mobile phone penetration has positive short run and long term effects on inclusive human development, the effects of internet and telephone penetrations are not significant. Furthermore, the long term inclusive human development benefits from mobile phone are higher than corresponding short term rewards.

The edge of the mobile phone could be traceable to the fact that it is more accessible to the poor compared with our other selected two forms of ICT, namely internet penetration and telephone penetration. First, the internet is comparatively more expensive. Unlike the mobile phone that requires an initial cost of purchase, after which the user engages the "pay as you go' option with minimum financial constraints and/or obligations, with the internet, considerable periodic financial obligations are required by the ICT operator or telecommunication company for the most part. Second, with regard to telephone subscriptions, it is important to note that many citizens in Sub Saharan Africa have more access to mobile phones compared to fixed phones that are considered to be relatively outdated. This narrative/justification is broadly supported by Lunden (2015). It follows from the above discourse that the fixed telephone and internet are more skewed towards the rich segments of the population.

In the light of the above, it is not enough to own a fixed phone and be connected to the internet in order to achieve inclusive development. Three primary reasons can be identified. 
First and foremost, a multitude of lives have been transformed with the help of the mobile phone because it enables previously unbanked users to have access to phone-related money storage and transfer systems. Therefore mobile phone penetration (both in terms of width and depth) is increasingly providing sampled countries with cost-effective mechanisms by which a hitherto financially-excluded segment of the population now has greater access to finance for, inter alia: better health services plus more and better quality education.

Second, the mobile telephone assists households of sampled countries in budget management, especially when they are confronted with unpredictable poverty-friendly externalities. The probability of a socio-economically underprivileged family to incur substantial losses owing to an unpredictable shock can be reduced if the household is able to timely respond to shocks. Therefore, compared to other ICT mechanisms, the mobile phone has the most apparent effects on inclusive human development because it decreases poverty consequences associated with shock experiences. Features in the better management of household finance and coping with shocks with the help of the mobile phone include: enhanced information access, lower transportation cost and better efficiency in responses to household shocks. In essence, when households of our sample of SSA countries are faced with critical economic, health and educational situations, quick positive feedbacks (with the mobile phone) can be associated with substantial cost-mitigation and saving of income. Therefore, it is relevant to involve security improvements that provide advantages in loss of poverty as a result of mobile phones. For example, a household's ability to mitigate the number of overnight days in the hospital and/or its ability to reduce transportation cost in critical scenarios is facilitated with the fast dial of a mobile phone. In summary, the device used for communication endows mechanisms by which the following are possible, inter alia: reduced surprises and timely responses, planning during shocks and multi-tasking.

Third, it is likely that the mobile phone empowers the female gender to run existing corporations more efficiently as well as to create new businesses. This ultimately enables the poor to bridge gender inequality and poverty gaps. The dimension of inequality is important because information rents previously enjoyed by the rich and more privileged factions of the population are reduced to a minimum, partly because of the wide accessibility to mobile phones. This inference is broadly consistent with a cross-sectional study by Asongu (2015d) which is based on correlations.

With respect to the established long term higher positive effects, mobile phones engender long-term per capita growth investment for the poor because households are for the 
most part usually prepared to cope with some short term sacrifices in the hope that the mobile phone will enhance income and job opportunities in the long term.

Two main theoretical contributions of the study are connected with the literature, notably catch-up in human development and use of ICT to mitigate information asymmetry for inclusive development.(i) Evidence of convergence is obvious because the estimated lagged values of the dependent variable are within the interval of zero and one (see Fung, 2009). This implies that countries with low levels of human development are catching-up their counterparts with higher levels of human development. Convergence in human development is an indication that cross-country common policies can be adopted contingent on ICT variables and other indicators in the conditioning information set. Such common policies could include improvement of cross-country ICT infrastructure and universal ICT access schemes. (ii) ICT decreases informational rents previously enjoyed by privileged factions of the population by improving the exchange and diffusion of information. Such should enhance the overall level of human well-being. This is broadly consistent with the theoretical underpinnings of efficiency in the financial intermediary sector by means of information sharing offices like public credit registries and private credit bureaus (see Claus \& Grimes, 2003; Tchamyou \& Asongu, 2017). Hence by analogy, the theoretical framework of sharing information for financial intermediary efficiency in the banking sector can be extended to the role of ICT in improving human well-being. This is essentially because with the information provided by means of ICT, available resources are more efficiently allocated to maximise living standards.

Future inquires can improve on existing literature by including country-specific factors for more targeted policy implications. Employing alternative indicators of inclusive human development is also worthwhile. 


\section{Appendices}

\section{Appendix 1: Definition and sources of variables}

\begin{tabular}{lllc}
\hline Variables & Signs & Definitions & Sources \\
\hline $\begin{array}{l}\text { Inclusive } \\
\text { development } \\
\text { Mobile Phone }\end{array}$ & IHDI & Inequality Adjusted Human Development Index & UNDP \\
Internet & Internet & Internet subscriptions (per 100 people) & WDI \\
Telephone & Telephone & Telephone subscriptions (per 100 people) & WDI \\
Foreign Aid & Aid & Total Official Development Assistance (\% of GDP) & WDI \\
Private Credit & Credit & Private credit by deposit banks and other financial institutions (\% of & WDI \\
& & GDP) & WDI \\
Remittance & Remit & Remittance inflows (\% of GDP) & WDI \\
Foreign & FDI & Foreign Direct Investment net inflows (\% of GDP) & WDI \\
investment & & & Mobile phone subscriptions (per 100 people)
\end{tabular}

Appendix 2: Summary statistics

Inequality Adj. Human Development

Mobile Phone Penetration

Internet Penetration

Telephone Penetration

Foreign Aid

Private Domestic Credit

Remittances

Net Foreign Direct Investment Inflows

\begin{tabular}{lllll} 
Mean & SD & Min & Max & Obs \\
\hline 0.721 & 3.505 & 0.129 & 0.768 & 485 \\
23.379 & 28.004 & 0.000 & 147.202 & 572 \\
4.152 & 6.450 & 0.005 & 43.605 & 566 \\
3.039 & 5.810 & 0.005 & 32.455 & 565 \\
11.687 & 14.193 & -0.253 & 181.187 & 606 \\
18.551 & 22.472 & 0.550 & 149.78 & 507 \\
3.977 & 8.031 & 0.000 & 64.100 & 434 \\
5.332 & 8.737 & -6.043 & 91.007 & 603
\end{tabular}

SD: Standard deviation. Min: Minimum. Max: Maximum. Obs: Observations. Adj: Adjusted. 
Appendix 3: Correlation Matrix (Uniform sample size: 324)

\begin{tabular}{|c|c|c|c|c|c|c|c|c|}
\hline Foreign aid & Credit & Remittances & FDI & Mobile & Internet & Telephone & IHDI & \\
\hline \multirow[t]{8}{*}{1.000} & -0.173 & -0.037 & 0.411 & -0.165 & -0.196 & -0.223 & -0.382 & Foreign aid \\
\hline & 1.000 & -0.084 & -0.065 & 0.514 & 0.511 & 0.614 & 0.529 & Credit \\
\hline & & 1.000 & 0.115 & -0.050 & -0.035 & -0.062 & -0.027 & Remittances \\
\hline & & & 1.000 & 0.111 & 0.072 & -0.029 & -0.001 & FDI \\
\hline & & & & 1.000 & 0.749 & 0.504 & 0.626 & Mobile \\
\hline & & & & & 1.000 & 0.669 & 0.649 & Internet \\
\hline & & & & & & 1.000 & 0.747 & Telephone \\
\hline & & & & & & & 1.000 & IHDI \\
\hline
\end{tabular}

Credit: Private domestic credit. FDI: Foreign Direct Investment. Mobile: Mobile Phone Penetration. Internet: Internet Penetration. Telephone: Telephone Penetration. IHDI: Inequality Adjusted Human Development Index.

\section{References}

Aker, J. C., \&Fafchamps, M., (2010). "How Does Mobile Phone Coverage Affect Farm-Gate Prices? Evidence from West Africa", Department of Economics and the Fletcher School, Tufts University.

Al Surikhi, H. F., (2012). "Knowledge and Financial Management in Households: An Examination of Married Women's Perspectives in Chadbourn, North Carolina", Capstone Collection, Paper No. 2489, Vermont.

Anand, R., Mishra, S., \&Spatafora, N., (2012). "Structural Transformation and the Sophistication of Production," IMF Working Paper No. 12/59, Washington.

Anyanwu, J. C., (2012). "Developing Knowledge for the Economic Advancement of Africa", International Journal of Academic Research in Economics and Management Sciences, 1(2), pp. 73-111.

Anyanwu, J. C., (2013a). "The correlates of poverty in Nigeria and policy implications", African Journal of Economic and Sustainable Development, 2(1), pp. 23-52.

Anyanwu, J. C., (2013b). "Gender Equality in Employment in Africa: Empirical Analysis and Policy Implications”, African Development Review, 25(4), pp. 400-420.

Anyanwu, J. C., (2014a). "Determining the correlates of poverty for inclusive growth in Africa", European Economics Letters, 3(1), pp. 12-17.

Anyanwu, J. C., (2014b). "Marital Status, Household Size and Poverty in Nigeria: Evidence from the 2009/2010 Survey Data", African Development Review, 26(1), pp. 118-137.

Arellano, M., \& Bond, S., (1991)."Some tests of specification for panel data: Monte Carlo evidence and an application to employment equations" The Review of Economic Studies,58(2), pp. 277-297. 
Arellano, M., \&Bover, O., (1995). "Another look at the instrumental variable estimation of errorcomponents models", Journal of Econometrics, 68(1), pp. 29-52.

Arvin, B. M., \& Lew, B., (2010a). "Aid and happiness: untangling the causal relationship in nine European donor countries", Global Business and Economic Review, 12(4), pp. 341-358.

Arvin, B. M., \& Lew, B., (2010b). "Does Happiness Affect the Bilateral Aid Flows Between Donor and Recipient Countries?",The European Journal of Development Research, 22(4), pp. 546-563.

Arvin, B. M., \& Lew, B., (2011). "Are foreign aid and migrant remittances sources of happiness in recipient countries", International Journal of Public Policy, 7(4/5/6), pp. 282300.

Arvin, B. M., \& Lew, B., (2012a). "Do happiness and foreign aid affect bilateral migrant remittances?”,Journal of Economic Studies, 39(2), pp. 212-230.

Arvin, B. M., \& Lew, B., (2012b)."Development Aid, Corruption and the Happiness of Nations: Analysis of 118 countries over the years 1996-2009", Applied Econometrics and International Development, 12(2), pp. 69-78.

Asongu, S. A., (2013a). "How has mobile phone penetration stimulated financial development in Africa", Journal of African Business, 14(1), pp. 7-18.

Asongu, S. A., (2013b). "Harmonizing IPRs on Software Piracy: Empirics of Trajectories in Africa", Journal of Business Ethics, 118(1), pp. 45-60.

Asongu, S. A., (2014a). "Mobile banking and mobile phone penetration: which is more propoor in Africa?",African Governance and Development Institute Working Paper No.13/033, Yaoundé.

Asongu, S. A., (2014b). "African development: beyond income convergence", South African Journal of Economics, 83(3), pp. 334-353.

Asongu, S. A., (2014c). "Software Piracy and Scientific Publications: Knowledge Economy Evidence from Africa", African Development Review, 26(4), pp. 572-583.

Asongu, S. A., (2014d). "Software piracy, inequality and the poor: evidence from Africa", Journal of Economic Studies, 41(4), pp. 526-553.

Asongu, S. A., (2014e). "The Questionable Economics of Development Assistancein Africa: Hot-Fresh Evidence, 1996-2010", The Review of Black Political Economy, 41(4), pp. 455480 .

Asongu, S. A., (2015a). "Knowledge Economy Gaps, Policy Syndromes and Catch-Up Strategies: Fresh South Korean Lessons to Africa", Journal of the Knowledge Economy, DOI:10.1007/s13132-015-0321-0.

Asongu, S. A. (2015b). "The Comparative Economics of Knowledge Economy in Africa: Policy Benchmarks, Syndromes and Implications", Journal of the Knowledge Economy, DOI: 10.1007/s13132-015-0273-4 
Asongu, S. A., (2015c). "Conditional Determinants of Mobile Phones Penetration and Mobile Banking in Sub-Saharan Africa", Journal of the Knowledge Economy.DOI: $10.1007 \% 2$ Fs $13132-015-0322-\mathrm{z}$

Asongu, S. A., (2015d). "The impact of mobile phone penetration on African inequality", International Journal of Social Economics, 42(8), pp. 706-716

Asongu, S. A., \& De Moor, L., (2016). "Financial globalisation dynamic thresholds for financial development: evidence from Africa", European Journal of Development Research: DOI:10.1057/ejdr.2016.10.

Asongu, S. A., Efobi, U., \& Beecroft, I., (2015). "Inclusive Human Development in Pre-Crisis Times of Globalisation-Driven Debts", African Development Review: 27(4), pp. 428-442.

Asongu, S. A., \& Nwachukwu, J. C., (2016a).“The role of governance in mobile phones for inclusive human development in Sub-Saharan Africa", Technovation, 55-56(SeptemberOctober), pp. 1-13.

Asongu, S. A., \& Nwachukwu, J. C., (2016b). "Mobile phones in the diffusion of knowledge and persistence in inclusive human development in Sub-Saharan Africa", Information Development, DOI: 10.1177/0266666916655189.

Asongu, S. A., \& Nwachukwu, J. C., (2016c). "The Mobile Phone in the Diffusion of Knowledge for Institutional Quality in Sub-Saharan Africa", World Development, 86(October), pp. 133-147.

Asongu, S. A., \& Nwachukwu, J., (2016d)."Revolution empirics: predicting the Arab Spring”,Empirical Economics, 51(2), pp. 439-482.

Asongu, S. A., \& Nwachukwu, J. C., (2016e). "Foreign aid and inclusive human development: updated evidence from Africa, 2005-2012", Social Science Quarterly, DOI: $10.1111 /$ ssqu.12275/

Baliamoune-Lutz, M., (2007). "Globalisation and Gender Inequality: Is Africa Different?”,Journal of African Economies, 16(2), pp. 301-348.

Baliamoune-Lutz, M., \& McGillivray, M., (2009). “Does Gender Inequality Reduce Growth in Sub-Saharan Africa and Arab Countries?",African Development Review, 21(2), pp. 224242.

Baltagi, B. H., (2008). "Forecasting with panel data", Journal of Forecasting, 27(2), pp. 153173.

Barro, R., (1991). "Economic Growth in a Cross Section of Countries".Quarterly Journal of Economics, 196 (2/May), pp. 407-443.

Barro, R. J., \& Sala-i-Martin, X., (1992). “Convergence”, Journal of Political Economy, 100(2), pp. 223-251. 
Barro, R. J., \& Sala-i-Martin, X., (1995).Economic Growth.The MIT Press, Cambridge, MA.

Bauer, S., De Niet, J., Timman, R., \&Kordy, H., (2010).“Enhancement of care through selfmonitoring and tailored feedback via text messaging and their use in the treatment of childhood overweight", Patient Education and Counseling, 79 (2010), pp. 315-319.

Beck, T., Demirgüç-Kunt, A., \& Levine, R., (2003), "Law and finance: why does legal origin matter?",Journal of Comparative Economics, 31(4), pp. 653-675.

Baumol, W. J., (1986). "Productivity, growth, convergence and welfare: what the long run data show", American Economic Review, 76(5), pp. 1072-1085.

Blundell, R., \& Bond, S., (1998). "Initial conditions and moment restrictions in dynamic panel data models",Journal of Econometrics, 87(1), pp. 115-143.

Bond, S., Hoeffler, A., \&Tample, J. (2001) “GMM Estimation of Empirical Growth Models", University of Oxford.

Bruno, G., De Bonis, R., \&Silvestrini, A., (2012). "Do financial systems converge? New evidence from financial assets in OECD countries".Journal of Comparative Economics, 40(1), pp. 141-155.

Chan, A., \&Jia, T., (2011). "The Role of Mobile Banking in Facilitating Rural Finance: Reducing Inequality in Financial Services between Urban and Rural Areas", Accenture Banking Services, http://www.accenture.com/SiteCollectionDocuments/PDF/PoV-MobileBanking-051611-EN.pdf (Accessed: 17/03/2015).

Claus, I., \& Grimes, A., (2003). "Asymmetric Information, Financial Intermediation and the Monetary Transmission Mechanism: A Critical Review", NZ Treasury Working Paper No. 13/019, Wellington.

Da Costa, T. M. Salomão, P. L., Martha, A. S., Pisa, I. T., \&Sigulem, D., (2010). “The impact of short message service text messages sent as appointment reminders to patients' cell phones at outpatient clinics in São Paulo, Brazil", International Journal of Medical Informatics, 79 (2010), pp. 65-70.

Demombynes, G., \&Thegeya, A. (2012). "Kenya's mobile revolution and the promise of mobile savings", World Bank Policy Research Working Paper No. 5988, World Bank, Washington, DC.

Dewan, S., \&Ramaprasad, J., (2014). "Social media, traditional media and music sales", MIS Quarterly, 38(1), pp. 101-128.

Dollar, D., \&Kraay, A., (2003). "Institutions, Trade, and Growth," Journal of Monetary Economics, 50, (1), pp. 133-162.

E-agriculture (2012). "Using ICT to enable Agricultural Innovation Systems for Smallholders", e-source book, ICT In Agriculture, Connecting Small Holders to Knowledge, Networks and Institutions, (Forum 4, September 2012).

http://www.fao.org/docrep/018/ar130e/ar130e.pdf (Accessed: 18/03/2015). 
Elu J. \& Loubert, L. (2013). "Earnings Inequality and the Intersectionality of Gender and Ethnicity In SubSaharan Africa: The Case of Tanzanian Manufacturing", American Economic Review, Papers and Proceedings 04/2013, 103(103), pp. 289-292.

Fosu, A. K., (2015a). "Growth, Inequality and Poverty in Sub-Saharan Africa: Recent Progress in a Global Context”, Oxford Development Studies, 43(1), pp. 44-59.

Fosu, A.,(2015b). Growth and Institutions in African Development, First edited by Augustin K. Fosu, , Routledge Studies in Development Economics: New York

Fosu, A., (2015c). Growth and institutions in African Development, in Growth and Institutions in African Development, First edited by Augustin K. Fosu, 2015, Chapter 1, pp. 1-17, Routledge Studies in Development Economics: New York.

Fung, M. K., (2009). "Financial development and economic growth: Convergence or divergence?”,Journal of International Money and Finance, 28(1), pp. 56-67.

Hoffman, J. A., Cunningham, J. R., Suleh, A. J., Sundsmo, A., Dekker, D., Vago, F., \&Munly, K., (2010). "Mobile Direct Observation Treatment for Tuberculosis Patients A Technical Feasibility Pilot Using Mobile Phones in Nairobi, Kenya", American Journal of Preventive Medicine, 39(1), pp. 78-80.

Jonathan, D., \& Camilo, T. (2008)."Mobile banking and economic development: Linking adoption, impact and use". Asian Journal of Communication, 18(4), 318-322.

Jones, S., Page, J., Shimeles, A., \& Tarp, F., (2015). "Aid, Growth and Employment in Africa", African Development Review, Supplement: Special Issue on "Aid and Employment", 27, ( S1), pp. 1-4.

Jones, S., \& Tarp, F., (2015). "Priorities for Boosting Employment in Sub-Saharan Africa: Evidence for Mozambique", African Development Review, Supplement: Special Issue on "Aid and Employment", 27,( S1), pp. 56-70.

Kirui, O. K., Okello, J. J., Nyikal, R. A., \&Njiraini, G. W., (2013). "Impact of Mobile PhoneBased Money Transfer Services in Agriculture: Evidence from Kenya", Quaterly Journal of International Agriculture, 52(2), pp. 141-162.

Klasen, S., (2005)."Economic Growth and Poverty Reduction: Measurements and Policies", Paris, Working paper No. 246, OECD Development Center, Paris.

Kliner, M., Knight, A., Mamvura, C., Wright, J., \&Walley, J., (2013).“Using no-cost mobile phone reminders to improve attendance for HIV test results: a pilot study in rural Swaziland", Infectious Diseases of poverty, 2(12), pp. 1-7.

Kuada, J., (2015). Private Enterprise-Led Economic Development in Sub-Saharan Africa The Human Side of Growth First edition by Kuada, J, Palgrave Macmillan: New York.

Lopez, H., \&Serven, L. (2004), “The Mechanics of Growth-Poverty-Inequality Relationship”, mimeo. 
Love, I., \&Zicchino, L., (2006).“Financial Development and Dynamic Investment Behaviour: Evidence from Panel VAR" .The Quarterly Review of Economics and Finance, 46(2), pp. 190-210.

Lunden, I., (2015). “6.1B Smartphone Users Globally By 2020, Overtaking Basic Fixed Phone Subscriptions", techcrunch, https://techcrunch.com/2015/06/02/6-1b-smartphone-users-globally-by-2020-overtakingbasic-fixed-phone-subscriptions/ (Accessed: 06/08/2016).

Mankiw, N. G., Romer, D., \& Weil, D. N., (1992). "A contribution to the empirics of economic growth”, Quarterly Journal of Economics, 107 (May, 1992), pp. 407-437.

Maurer, B. (2008, May). Retail electronic payments systems for value transfers in the developing world.Department of Anthropology, University of California.

Mayer-Foulkes, D., (2010).'Divergences and Convergences in Human Development".UNDP Human Development Research PaperNo. 2010/20, New York.

McDonald, J., (2009), "Using Least Squares and Tobit in Second Stage DEA Efficiency Analyses”, European Journal of Operational Research, 197(2), pp. 792-798.

Michel, J., (2016). "Beyond Aid: the Integration of Sustainable Development in a Coherent International Agenda", Centre for International Private Enterprises, http://www.cipe.org/publications/detail/beyond-aid-integration-sustainabledevelopmentcoherent-international-agenda(Accessed: 19/07/2016).

Mishra, V., \&Bisht, S. S., (2013)."Mobile banking in a developing economy: A customercentric model for policy formulation", Telecommunications Policy, 37(6-7), pp. 503-514.

Mishra, S., Gable, S. L., \&Anand, R., (2011), "Service Export Sophsitication and Economic Growth," World Bank Policy Working Paper No. 5606, Washington.

Mlachila, M., Tapsoba, R., \&Tapsoba, S. J. A., (2014). "A Quality of Growth Index for Developing Countries: A Proposal”, IMF Working Paper No. 14/172, Washington.

Mpogole, H., Usanga, H., \&Tedre, M., (2008)."Mobile phones and poverty alleviation: a survey study in rural Tanzania", Proceedings of M4D 2008, Karlstad University, Sweden, pp. $62-72$.

Muto, M., \&Yamano, T., (2009). "The Impact of Mobile Phone Coverage Expansion on Market Participation: Panel Data Evidence from Uganda", World Development, 37(12), pp. 1887-1896.

Narayan, P.K., Mishra, S., \& Narayan, S., (2011). "Do market capitalization and stocks traded converge? New global evidence".Journal of Banking and Finance, 35(10), pp.2771-2781.

Ojo, A., Janowski, T., \&Awotwi, J., (2012).“Enabling development through governance and mobile technology", Government Information Quarterly, 30 (2013), pp. S32-S45.

Oluwatobi, S.,Efobi, U.R., Olurinola, O.I., Alege, P. (2015), "Innovation in Africa: Why Institutions Matter", South African Journal of Economics, 83(3), pp. 390-410. 
Ondiege, P., (2013). "Fostering financial inclusion with mobile banking", African Development Bank. http://www.proparco.fr/webdav/site/proparco/shared/PORTAILS/Secteur_prive_developpeme nt/PDF/SPD16/SPD16_Peter_Ondiege_UK.pdf (Accessed: 03/02/2015).

Ondiege, P., (2010). "Mobile Banking in Africa: Taking the Bank to the People", Africa Economic Brief, 1(8), pp. 1-16.

Penard, T., Poussing, N., Yebe, G. Z., \& Ella, P. N., (2012).“Comparing the Determinants of Internet and Cell Phone Use in Africa: Evidence from Gabon", Communications \& Strategies, 86, pp. 65-83.

Prochniak, M., \&Witkowski, B., (2012a)."Beta convergence stability among "Old" and "New" EU countries: The Bayesian Model Averaging Perspective", Warsaw School of Economics.

Prochniak, M., \&Witkowski, B., (2012b). "Real economic convergence and the impact of monetary policy on economic growth of the EU countries: The analysis of time stability and the identification of major turning points based on the Bayesian methods", Warsaw School of Economics.

Qiang, C. Z., Kuek, S. C., Dymond, A., \&Esselaar, S., (2011). "Mobile Applications for Agricultural and Rural Development", ICT Sector Unit, World Bank http://siteresources.worldbank.org/INFORMATIONANDCOMMUNICATIONANDTECHN OLOGIES/Resources/MobileApplications_for_ARD.pdf (Accessed: 17/03/2015).

Ravallion, M., \& Chen, S., (2003). "Measuring Pro-Poor Growth," Economics Letters, 78(1), pp. 93-99.

Roodman, D., (2009a). "A Note on the Theme of Too Many Instruments", Oxford Bulletin of Economics and Statistics, 71(1), pp. 135-158.

Roodman, D., (2009b). "How to do xtabond2: An introduction to difference and system GMM in Stata", Stata Journal, 9(1), pp. 86-136.

Seneviratne, D., \& Sun, Y., (2013), "Infrastructure and Income Distribution in ASEAN-5: What are the Links?" IMF Working Paper No. 13/41, Washington.

Simpasa, A, Shimeles, A., \& Salami, A. O., "Employment Effects of Multilateral Development Bank Support: The Case of the African Development Bank", African Development Review, Supplement: Special Issue on "Aid and Employment", 27,( S1), pp. 3143.

Singh, A. B., (2012). "Mobile banking based money order for India Post: Feasible model and assessing demand potential”, Procedia - Social and Behavioral Sciences, 37, pp. 466-481.

Solow, R. M., (1956). "A contribution to the theory of economic growth", Quarterly Journal of Economics, 70(1), pp. 65-94. 
Ssozi, J., \&Amlani, S., (2015) "The Effectiveness of Health Expenditure on the Proximate and Ultimate Goals of Healthcare in Sub-Saharan Africa", Economics Department, Hankamer School of Business, Baylor University.

Swan, T., (1956).“Economic growth and capital accumulation”.Economic Record, 32(2), pp. 334-361.

Tchamyou, V. S., (2016). "The role of knowledge economy in African business", Journal of the Knowledge Economy,DOI: 10.1007/s13132-016-0417-1.

Tchamyou, S. V., \& Asongu, S. A., (2017). "Information Sharing and Financial Sector Development in Africa", Journal of African Business, 18(1), pp. 24-49.

Warren, M., (2007). "The digital vicious cycle: links between social disadvantage and digital exclusion in rural areas". Telecommunications Policy, 31(6-7), pp. 374-388.

West, D. M., (2013). "Improving Health Care through Mobile Medical Devices and Sensors", Centre for Technology and Innovation at Brookings, http://www.brookings.edu/ /media/research/files/papers/2013/10/22\%20mobile\%20medical \%20devices\%20west/west_mobile\%20medical\%20devices_v06 (Accessed: 19/03/2015).

World Bank (2015). "World Development Indicators", World Bank Publicationshttp://www.gopa.de/fr/news/world-bank-release-world-development-indicators$\underline{2015}$ (Accessed: 25/04/2015). 